\title{
Effect of Credit Zip Code Application onReducing Bank Credit Risks: Case Study on a Sample of Saudi Banks
}

\author{
YousifMonaha \\ Assist. Professor of Administration and Economy, Community College, Najran University, KSA
}

\begin{abstract}
The current study is an attempt to identify the effect of Credit Zip Code application on reducing bank credit risks in Saudi Arabia and to getfunding operations and interestsmore secured. The study adopted the descriptive and analytical method. A questionnaire was utilized as a tool for data collection after verifying its validity and reliability; it was distributed to the staff of some Saudi banks, finance and sales departments, who were randomly selected.Number of 70 questionnaires were distributed, 66 were restored with 6 waste questionnaires and 60 questionnaires were able to be statistically analyzed which represents (85.7\%) of the total questionnaires. Data were discharged \& statistically analyzed by using "SPSS-18" software; questionnaire has two divisions, the first represented sample features and the second division has two domains represented questionnaire inquiries, study validity \& reliability were examined by Cronbach's Alpha laboratories test, that ensured it as it indicated $(.81 \& .900)$ as validity \& reliability rating. The results of the first domain of the study showed that the averagepercentage of agreementrated(98.8\%), and the average response was (4.58), standard deviation was (0.52), and T-value was (11.80), significant at the level of (0.01). The results of the second domain of the study indicated that the average percentage of agreementrated (93.8\%), and the average response was (4.43), with standard deviation of (0.63), and T-value was (12.1), significant at the level of (0.01). The study concluded that the total data and information provided by the application of credit Zip code system tobank customersreduce bank credit risks and bad loan, and to get banking funded operations more effective. The study recommended that Credit Zip Code system should be circulated to all Saudi banks to get more secured and free of bank financing risks and bad funding.
\end{abstract}

Keywords: Credit Zip Code, bank credit risks, Saudi banks

\section{Introduction}

Banking industry plays an important role in countries economics; due to the large and accelerated developments which had occurred in all life aspects, new financial products have emerged, major complications face the environment in which financial firms and banks operate, also have led it to practice more risks, that push the central banks, bankingregulatory authorities, commercial banks \& financial firms management and those who interested in banking sector issues to search and evaluate these risks and put policies, proactive \& preventive procedures to control it and achieve secured banking.Therefore, the sound understanding of how to manage banking risk, risks self-evaluation and its controlling procedures, have become the first defense line in protecting the rights of depositors, creditors and shareholders as well, and become one of the main pillars to achieve secured banking and financial \& banking stability reinforcement that obviously appeared in Basel 11 first \& second decisions requirements which generally focused on different banking risks management and funding risks specifically which specialists have agreed that it represents more than $60 \%$ of average total risks in different countries, so the banking \& financial firms officials had to find effective solutions to decrease those risks by searching on effective alternatives to contribute positively in increasing the return of banking fund and decrease the waste to the least extent.

\section{Statement of the Problem}

\section{Methodology}

1) Does credit Zip code application contribute to providing comprehensive information \& data about the client which reduced bank credit risks \& bad funding?

2) Does credit Zip code application contribute to providing comprehensive data about the funded operation to be directed effectively to reduce bank credit risks?

Research Hypotheses

1- Comprehensive information \& data about the banking sector customers provided by credit Zip code applicationsystem are reducing bank credit $\&$ bad funding risks.

2- Applying credit Zip code system provides information that lead to direct the funded banking operations effectively that reduces bank credit risks. 


\section{Objectives}

Study attempted to identify the effect of Credit Zip Code application on reducing bank credit risks and its role in achieving secured bank funding operations, and the benefits which returned to all beneficiaries (client, bank, total economy, bankingregulatory authority, and ordinary citizen) due to system applying.

\section{Research Methodology}

The study adopted the descriptive, analytical and statistical method to bring and extract ideas \& conceptions which dealt generally with bank credit Zip code and its applications subjects in Saudi banks Researcher would depend on scientific references \& resources, annual reports and research papers that reviewed this subject.

\section{Literature Review}

Many previous studies have discussed this subject from other different aspects; this study illustrated the credit Zip code issue on a sample of Saudi banks from its practical side to cover the shortage in the subject research field, one of those studies, Roushdy Abdul Fatah Saleh'sstudy"ComprehensiveBanks and Egyptian Banking Board Development (national \& international comprehensive banking", without a publisher, Alexandria 2000 ; Ahmed Ghaim'sstudy," Credit and Funding Donation Decisions through Overall Strategy", Egypt 2002 ;Abdul MoatyRedaArshid\& Mahfouz Ahmed Gouda's study," Credit Management", Dar Waelfor publishing, Amman, first edition 2003 ; BeghzazYaadel Farida's study," Policies and techniques of Banking Operating", university publishing office second edition, Algeria, 2003;

TarekAbd El AalHammad's study," International Changes and its Reflections on Banks Works", el dar el gamieya, Egypt, 2003 .; GhalebAwad El Refaay\&SaadGhalebYassin's study " Information Department Role in Reducing Credit Risks (Field Study)', El Zaitouna Jordanian University, Amman, Jordan 2004 ; TarekAbd El AalHammad's study " Companies Governance, conceptions, principles \& experiences" " Bank Governance Applications", el dar el gamieya, Alexandria, 2005 ; Ben Aliia Ahmed's study " Banks Techniques in Loan Donation", graduation memo to get license certificate, El Aghwatt University, year 2005 ;Samir $\quad$ El Khatib," Measure \& Manage Banks Risks", Monshaet El Maaref, Egypt, 2005;DoaaSaad El DeenBakry Ahmed's study "Accounting Analysis by using financial Breakdown Prediction to Decrease Bank Credit Risks", financial \& commercial studies magazine, faculty of commerce, BeniSwef university, second and third editions, master research published in 2005;Nabil Hashad's study (2006 )," Your Guidance for in \& out Credit Classifications", Teshreen university magazine for scientific studies and researches, economical \& legal sciences, 2006 ; MoftahSaleh\&Maarefy Farida's study," Credit Risks - analyzing, measuring, managing and controlling it", Beskarah university, Algeria 2007; Rahim Hussein's study," Electronic Banking as an Introduction to Modernize Algerian Banks", scientific texts group for the first national meeting about Algerian banking system and the economic changes, fact and aspiration, 2007 ; Muhammad Saad El Kowary's study "Credit Agencies and its Effect on developing the financial sector", research paper to attain master degree in Islamic funding presented by Islamic studies faculty in Qatar foundation for science, education and society development, Doha, Qatar, published 2010; Ali Abdullah Ahmed Shahin's study " Practical Introduction for Bank Credit Risks Measurement in Palestine Commercial Banks", Islamic university, Ghaza, April 2010 ; Abdullah El Hassan Muhammad's study" Credit Information Role in Banks Performance Promotion", research paper published in El Masrafy magazine, central bank release in 2012 ; Kamal Rezaif' study, the research paper " Precaution and Risks Management in Algeria Banks and Financial Firms, El Bolaidah University, Algeria, 2012 ; and many other studies which field could not be wide enough to be mentioned, only few studies have been mentioned in study margin.

\section{Credit Zip Code}

Credit Zip Code is a mechanism that collects information from creditors, available public sources and borrowers' credit history, about individuals and companies, especially, the related records of credit / fund payment, courts decisions, bankruptcy and its electronic modification \& keepingusing it in case of need.

Rahim Hussein (2007), identified that it is an electronic symbol for every customer to be distinguished, not to be repeated and to be more accurate in case of names similarities.

\section{Credit Zip Code Stages}

Roushdy 2000, pointed that it includes four stages, the first stage;the one of customers' data collecting, data related transactions organizing and coding.This stage is distinguished by its continuity due to the renewal nature of the banking system's clients, the second stage to gather clients' link data with the parties which they have a relationwith (the coherent parties) and also it has the continuity of its former, the third stage is for collecting financial data, and it cares about gathering the current \& previous financial data of the banking board's clients, the last stage to gather clients' data, in which the technical system of clients' financial 
\&demographic data is tested and to be assured of the effectiveness and the credit, regulatory \& statistical reports as an introduction to start working with credit Zip code system.

\section{Credit Zip Code Advantages}

The most prominent advantages of applying the credit Zip code system are summarized in the following: Firstly: Bank's Advantages:

To get full clients' data and solve the problem of names similarities problems, that helps in following funding operations effectively through customers' detailed credit reports which make it easier to have a quick decisions in collecting loans fast and reduce bad funding operations, or encourages the bank to raise the credit limit per customer if the safety proved, also it provides credit information agencies for the banking board customers.

\section{Secondly: Customers'Advantages:}

Customers either depositors or borrowers benefit by their investment success \& its proceeds increment, by boosting their bank trust through fast procedures \& operations high quality, their money demand response is guaranteed, by raising credit limit or any other banking operations.

\section{Thirdly: Country Macroeconomics' Advantages:}

Beghzaz (2003) explained that global trust would be increased in country's economy, reduce bad funding that would be positively reflected in GDP (gross domestic product.), reduce unemployment rate, increase country's public treasuryproceeds, and other advantages for the banking regulatory authorities with the fast creation of regulatory \& statistical reports.

\section{Credit Zip Code Requirements}

Tarek (2005) showed that credit Zip code requirements are summarized in shaping strong legal and organizational framework, selecting the appropriate technique, ensuring the availability of adequate data and ensuring the commercial viability \&sources of information.

\section{Credit Zip Code Relation with Bank Fund}

Ben Aliia (2005), elucidated that the relation between the credit Zip code andbank funding is generated from being a good mechanism to reduce funding risks, reduce irregular financing and to increase bank transactions proceeds as credit Zip code project (and the publications and its controlled regulations) for customers is presented one of the most important arrangement adopted now by the global central banks, to get as much demographic data of banking board customers with concentricity on funding customers, analyze \& keep it, unify customer's personality to achieve unified funding situation to be dealt through, and make reaching the customer more easier in order to reduce many risks might be caused by customer.

\section{"Credit Information" Conception for Bank Board Customers:}

Abdullah (2012) identified the "credit information" that it is the service of collecting important information about bank loan applicant via credit report of banks \& financial firms customers and personal \& consuming loans organizations customers like installment selling, telecommunications companies and others at variance. This record contains demographic data that identify customer like the national ID, commercial record, export \& import record and credit data.

\section{Credit Information Significance:}

Abdullah (2012), represented the significance of credit information to the banking industry in limiting bad fund phenomena so it would increase the base of funded customers who are trusted with their regular repayment, and refund them again that lead to production increment and saving services\& goods of the national economy(previous reference).

\section{Credit Records Types:}

Credit records are divided into two main types:

\section{Firstly: Debit (Credit) Record:}

Ali (2010), explained that this record is managed by the public sector especially country's central bank, it works on determination credit information sources (banks \& financial firms), also it arranges credit information purposes and its authorized entities, the central banks is considered the most important supervisory $\&$ regulatory entity on exposure risks in banksand on funding \& funded customers' data. 


\section{Secondly: Debtors' Record:}

Nabil (2006), showed that this record is owned \& managed by the private sector after getting the central bank authorization who puts rules, regulations and supervisory principles of these private offices \& companies that attain information from its private resources for fees; banks \& the financial companies often participated in these private companies foundation to keep a database of debtors, used for having the decisions of funding application by the shareholder companies, other than these companies, this service could be used by telecommunication companies and infrastructure companies such as water, electricity companies and others.

\section{Credit Information Systems:}

Central banks create these systems to achieve regulatory goals on banks \& financial organizations and usually be in the central bank or independent entity established by regulator law, gives it the power to oblige the responsible entities to provide credit data $\&$ info of the funded customers from the banks $\&$ financial firms. It is given the authority to make the data base, manage it and make it secured by private software; and it gives the authority of credit information for authorized officials in order to preserve the confidentiality of customers' information; central bank issues certain controls \& explanatory memos to control the circulated information (previous reference).

\section{Three systems for credit information:}

1- Official Credit Information Systems:

Request presented by banks to the central bank to get information about intended to be funded customer.

2- Credit Information Systems Owned by Creditors:

Systems to provide credit information services are established by banks \& financial organizations that present funding \& credit facilities for customers, to swap credit information and to provide credit information to its shareholders. Central bank contributes with strategic share to increase controlling and supervision on its operations.

\section{3- Independent Credit Information Systems:}

Other independent persons \& firms establish companies that operate on credit information service unlike the other banks \& financial organizations that provide funding \& credit facilities. Those companies are authorized by the central bank after accomplishing accurate rules \& regulations and its database usually depends on official entities released info.

Fourthly: The Advantages of Credit Information Systems:

A range of important advantages are provided by credit information systems like:

Credit Reports Provision:

Moftah (2007) explained that the mentioned systems are providing the credit information service in credit reports forwarded to official entities. It is usually kept for five years or more, customer's credit information is often banked up for two years, and it is noticed that the credit information reports in both credit information systems owned by creditors \&independent credit information systems are rather simple compared with official credit information systems reports.

\section{Credit Reports Types:}

\section{Free Report (New Customer):}

Customer's identifying \& demographic data are showed without any credit data as customer has not been funded before.

Basic Report:

Overall demographic \& credit data are showed with customer's obligations towards the banking board.

Standard Report:

Detailed demographic \& credit data are showed with customer's obligations, in default and in arrears settlements.

\section{Advanced Report:}

Current, previous demographic \& credit data are showed in details with any occurred modifications.

\section{Comprehensive Report:}

Samir (2005), said that all the detailed demographic \& credit data are presentedwith its current, previous form with the modifications occurred on it, obligations, in default and in arrears settlements for the banks \& financial firms that have presented funds\& credit facilities with its name.

\section{Bank Performance Promotion:}

Ghaleb\&Saad (2004), explained that the role of customers' credit information in promoting banks performance could be showed in its expected effect on banks performance according to resources attracting indicators by expecting that credit information would increase attracting new valued customers for the bank, who would proceed on known economic business, and deal with other customers who also practice actual economic activities that would lead to increase their confidence in banking body, recruit the resources by 
increasing employment rate as they choose the customer who has good credit record \& economic activity that would broaden customers base, growth of credit portfolio \& bank direct investment by possession assets helping in customers funding via effective fund forms, also reducing bad loans rating, credit information is expected to make bank fund decision \& make credit facilities or not neutrally and clearly, accordingly would help to have the right decisions to select valued customer who pays his financial obligations regularly then bad loans would be reduced, decreasing doubtful loans appropriations so it would be rare to ruin or erase debits, and raise banks' profits \&banks shareholders' profits would push them to participate in establish new banks.

\section{Developing the Credit Information System:}

Firstly: World Credit Information System Development:

Tarek (2003) said that, initiatives sponsored by international financial organizations such the International Bank \& the International Monetary Fund appeared to protect banks, financial firms and funds from the expected bad fund risks, to define their customer specifically and keep the international banking \& financial order away from bank risks and financial crises.

\section{Secondly: Arab Credit Information System Development:}

Arab Monetary Fund (2004), clarified that the apex agreed with IFC to release joint initiative in the Arabian zone (where the Saudi banks have significant position for its financial liquidity volume) to develop credit information systems and create the sufficient legal, organizational and technical atmosphere to achieve those systems success.

\section{Credit Information Systems Objectives:}

Many objectives achieved by credit information systems:

Muhammad (2010), pointed that in studying the situations of credit information systems \& Arab countries credit central records and present its fix \& developing suggestions, spread the awareness of credit information culture and issues, providing experts \& specialized consultants in developing these systems and helping in emphasizing Arabian central banks abilities in regulations \& supervision on these systems to improve credit analysis efficiency to achieve the banking \& financial stability particularlyin the Arab countries and the global financial bank system in general.

\section{Procedures:}

Researcher showed the adopted procedures to conduct this study: sample, population \& tools, the validity \& reliability, statistical processing that used to analyze the results.

\section{Firstly: Population \& Sample:}

Study populationis consisted of the Saudi banks credit \& sales departments' employees; sample was randomly selected from the population and some arbitrators determined its number.

Number of 70 questionnaires were distributed, 66 were restored with 6 waste questionnaires and 60 questionnaires were able to be statistically analyzed which represents $(85.7 \%)$ of the total questionnaires.

Data were discharged \& statistically analyzed by using "SPSS-18" software; questionnaire has two divisions, the first represented sample features and the second division has two domains represented questionnaire inquiries, study validity \& reliability were examined by Cronbach's Alpha laboratories test, that ensured it as it indicated $(.81 \& .900)$ as validity $\&$ reliability rating.

Tools:

Researcher depended on questionnaire as a main tool for sample's data collection.

\section{Questionnaire Description:}

A letter was attached with the questionnaire to clarify the study subject, objective and questionnaire purpose. The questionnaire has two main divisions:

First Division: Sample Features.

Table (1): Firstly: Sample Features:

\begin{tabular}{|c|c|c|c|c|c|c|c|}
\hline \multicolumn{7}{|c|}{ Sample Distribution Due to Age and Years of Experience } & \multirow[b]{2}{*}{ Total } \\
\hline \multirow{3}{*}{ Age } & Data & $\begin{array}{l}\text { Less than } 30 \\
\text { years }\end{array}$ & $\begin{array}{l}\text { From } 30 \text { to } 39 \\
\text { years }\end{array}$ & $\begin{array}{l}\text { From } 40 \text { to } 49 \\
\text { years }\end{array}$ & $\begin{array}{l}\text { From } 50 \text { years } \\
\text { and more }\end{array}$ & & \\
\hline & Number & 24 & 48 & 34 & 14 & & 120 \\
\hline & Percentage & $20 \%$ & $40 \%$ & $28 \%$ & $12 \%$ & & $100 \%$ \\
\hline \multirow{3}{*}{$\begin{array}{l}\text { Years of } \\
\text { Experience }\end{array}$} & Data & $\begin{array}{lll}\begin{array}{l}\text { Less } \\
\text { years }\end{array} & \text { than } 5 \\
\end{array}$ & 5 to 9 years & 10 to 14 years & $\begin{array}{l}\text { From } 15 \text { to } 19 \\
\text { years }\end{array}$ & $\begin{array}{l}\text { More than } \\
20 \text { years }\end{array}$ & \\
\hline & Number & 7 & 19 & 36 & 24 & 34 & 120 \\
\hline & Percentage & $6 \%$ & $16 \%$ & $30 \%$ & $20 \%$ & $28 \%$ & $100 \%$ \\
\hline
\end{tabular}




\section{Second Division: Main Domains:}

It has two domains, first domain included (9) phrases represented the effect of credit Zip code application on customer, the second domain included (8) phrases represented the effect of credit Zip code application on funded operation. Sample's individuals were left to determine their responses against every phrase as per Likert five-tiered scale which contains five grades (strongly agree, agree, neutral, dis agree and strongly dis agree).

Data were processed and accurate results were collected using "SPSS-18" statistical software.

Validity \& Reliability:

To ensure questionnaire apparent reliability and its clarity \& wording phrases validity, researcher presented the questionnaire on study related arbitrators, and suggested modifications were adapted.

\section{Statistical Validity:}

To ensure questionnaire paragraphs, exploratory sample validity was examined by Cronbach's Alphamethod; results indicated high validity rating for every paragraph as shown in table (1) which gives the complete confidence in validity of study data and material.

Table No. (2): Cronbach's Alpha Transactions Summary

\begin{tabular}{|r|r|r|}
\hline Domains'paragraphs & Validity & Reliability \\
\hline First & .82 & .906 \\
\hline Second & .83 & .911 \\
\hline Third & .80 & .894 \\
\hline All Domains & .81 & .900 \\
\hline
\end{tabular}

\section{Data Analysis \&Hypothesis Test:}

Study hypothesis was examined by finding out the arithmetic means(Answers Strength) \& standards deviations for every questionnaire paragraph, all of those assumptions are descriptive questions according to Likert five-tiered scale (strongly agree, agree, neutral, dis agree and strongly dis agree), and to find arithmetic means; every answer was given a weight as following:

Strongly disagree $=1.0-1.80$

Disagree $\quad=1.81-2.60$

Neutral $\quad=2.61-3.40$

Agree $\quad=3.41-4.20$

Strongly agree $=4.21-5.0$

Also, all the standard deviations were accounted for all questionnaire items, to know the harmony level for identified hypotheses paragraphs answers; if the result is less than "one", that indicates the high harmony in sample answers.This harmony doesn't indicate the agreement of sample on hypothesis paragraphs, but there are dissent opinions, thus, variances in answers average could be accounted; and if these variances are abstracts that indicateshypothesis acceptance.So values \& its significances of T test to be accounted compared to significance level $5 \%$, if this value is high value and its significance is less than $5 \%$ that indicates abstract variances existence either nonexistence refusal ( $\mathrm{H} 0)$ or alternative hypothesis acceptance (accept $\mathrm{H} 1$ ).

\section{Discussion}

First Domain: The effect of credit Zip code Application on Customers' Information:

Table (3)

\begin{tabular}{|c|c|c|c|c|c|c|c|c|c|c|}
\hline No & Paragraph & \multicolumn{5}{|c|}{ Percentage $\%$} & \multicolumn{4}{|c|}{$\begin{array}{l}\text { Arithmetic Means, Standard Deviation and T test } \\
\text { for One Sample }\end{array}$} \\
\hline 1 & $\begin{array}{l}\text { Credit Zip Code } \\
\text { system application } \\
\text { saves all the required } \\
\text { info about customer } \\
\text { that helps in right } \\
\text { funding decision }\end{array}$ & $57.5 \%$ & $40.8 \%$ & $1.7 \%$ & $0.0 \%$ & $0.0 \%$ & 4.56 & 0.53 & 15.54 & 0.01 \\
\hline 3 & $\begin{array}{lcr}\text { Credit } & \text { Zip } & \text { Code } \\
\text { system application } \\
\text { saves credit info } \\
\text { about customers' in }\end{array}$ & $55.8 \%$ & $44.2 \%$ & $0.0 \%$ & $0.0 \%$ & $0.0 \%$ & 4.56 & 0.50 & 7.43 & 0.01 \\
\hline
\end{tabular}


Effect of Credit Zip Code Application onReducing Bank Credit Risks: Case Study on a Sample of

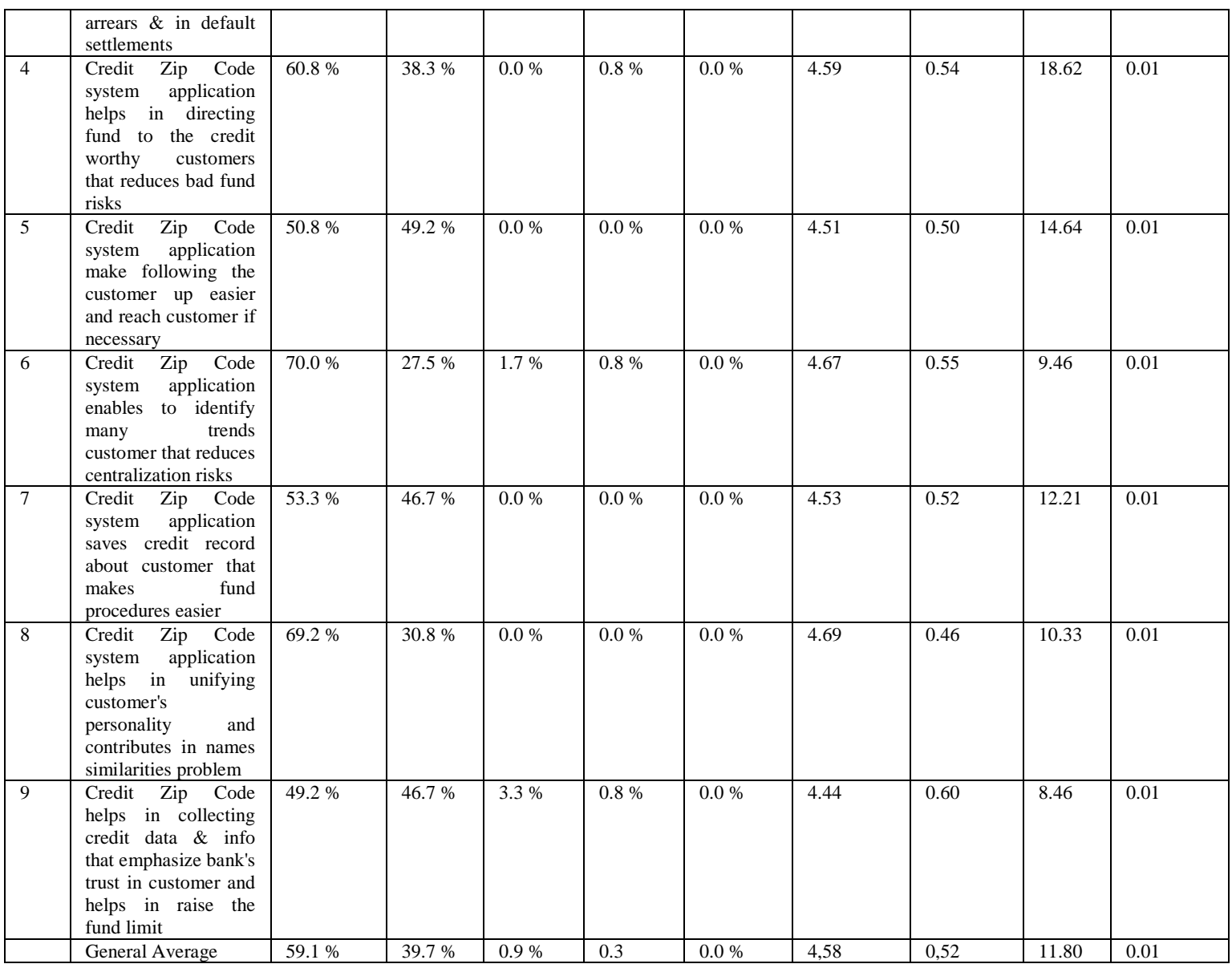

First Hypothesis Test: (comprehensive info \& data which provided by applying credit Zip code system about banks customers, reduce bank credit $\&$ bad fund risks).

With regard to table (3), first domain results indicated that agreements average percentage was $98.8 \%$, acceptances average was 4.58 with standard deviation reached 0.52 , and $\mathrm{T}$ value was 11.80 as its significance at (0.01) level.

*According to the mentioned above, we concluded refusal on nonexistence $(\mathrm{H} 0)$ and acceptance on alternative assumption (H 1).

Second Domain: The Effect of Credit Zip Code Application on Funded Operation Information:

Table (4)

\begin{tabular}{|c|c|c|c|c|c|c|c|c|c|c|}
\hline \multirow[t]{2}{*}{ No } & \multirow[t]{2}{*}{ Paragraph } & \multicolumn{5}{|c|}{ Percentage \% } & \multicolumn{4}{|c|}{$\begin{array}{l}\text { Arithmetic Means, Standard Deviation and T test for } \\
\text { One Sample }\end{array}$} \\
\hline & & $\begin{array}{l}\text { Strongly } \\
\text { Agree }\end{array}$ & Agree & Neutral & Disagree & $\begin{array}{l}\text { Strongly } \\
\text { Disagree }\end{array}$ & $\begin{array}{l}\text { Arithmetic } \\
\text { Means }\end{array}$ & $\begin{array}{l}\text { Standard } \\
\text { Deviation }\end{array}$ & $\begin{array}{l}\mathrm{T} \\
\text { Values }\end{array}$ & $\begin{array}{l}\text { Significant } \\
\mathrm{T}\end{array}$ \\
\hline 1 & $\begin{array}{l}\text { Credit Zip Code system } \\
\text { application saves all the } \\
\text { required info about fund } \\
\text { operation that helps in } \\
\text { right funding decision }\end{array}$ & $49.2 \%$ & $49.2 \%$ & $1.7 \%$ & $0.0 \%$ & $0.0 \%$ & 4.48 & 0.53 & 15.64 & 0.01 \\
\hline 2 & $\begin{array}{l}\text { Credit Zip Code system } \\
\text { application provides info } \\
\text { about fund worthy } \\
\text { operation that reduces } \\
\text { credit risks }\end{array}$ & $49.2 \%$ & $45.0 \%$ & $5.8 \%$ & $0.0 \%$ & $0.0 \%$ & 4.43 & 0.60 & 10.45 & 0.01 \\
\hline 3 & $\begin{array}{l}\text { Credit Zip Code system } \\
\text { application enables } \\
\text { following the funded } \\
\text { operation up effectively }\end{array}$ & $53.3 \%$ & $31.7 \%$ & $10.8 \%$ & $4.2 \%$ & $0.0 \%$ & 4.34 & 0.83 & 8.23 & 0.01 \\
\hline 4 & $\begin{array}{l}\text { Credit Zip Code system } \\
\text { application } \\
\text { directing the funded } \\
\text { operations effectively } \\
\text { that reduces bad fund } \\
\end{array}$ & $59.2 \%$ & $36.7 \%$ & $0.8 \%$ & $3.3 \%$ & $0.0 \%$ & 4.52 & 0.68 & 19.27 & 0.01 \\
\hline 5 & $\begin{array}{l}\text { Credit Zip Code system } \\
\text { application enables to }\end{array}$ & $50.8 \%$ & $46.4 \%$ & $2.5 \%$ & $0.0 \%$ & $0.0 \%$ & 4.48 & 0.55 & 11.61 & 0.01 \\
\hline
\end{tabular}


Effect of Credit Zip Code Application onReducing Bank Credit Risks: Case Study on a Sample of

\begin{tabular}{|c|c|c|c|c|c|c|c|c|c|c|}
\hline & $\begin{array}{l}\text { manage the funded } \\
\text { operations that ensures } \\
\text { the banking safety }\end{array}$ & & & & & & & & & \\
\hline 6 & $\begin{array}{l}\text { Credit Zip Code system } \\
\text { application helps in } \\
\text { managing the funded } \\
\text { operation risks better }\end{array}$ & $53.3 \%$ & $39.2 \%$ & $7.5 \%$ & $0.0 \%$ & $0.0 \%$ & 4.46 & 0,63 & 12.45 & 0.01 \\
\hline 7 & $\begin{array}{l}\text { Credit Zip Code system } \\
\text { application saves info } \\
\text { that helps in solving the } \\
\text { funded operations } \\
\text { problems before } \\
\text { reaching bad funding }\end{array}$ & $44.2 \%$ & $51.7 \%$ & $4.2 \%$ & $0.0 \%$ & $0.0 \%$ & 4.40 & 0.57 & 9.22 & 0.01 \\
\hline 8 & $\begin{array}{l}\text { Credit Zip Code system } \\
\text { application provides } \\
\text { comprehensive credit } \\
\text { reports \& data about } \\
\text { current \& previous } \\
\text { funded operations that } \\
\text { reduces credit risks }\end{array}$ & $43.3 \%$ & $47.5 \%$ & $9.2 \%$ & $0.0 \%$ & $0.0 \%$ & 4.43 & 0.64 & 10.32 & 0.01 \\
\hline & General Average & $50.31 \%$ & $43.46 \%$ & $5.31 \%$ & $9 . \%$ & $0.0 \%$ & 4.43 & 0.63 & 12.1 & 0.01 \\
\hline
\end{tabular}

SecondHypothesis Test: (Provided info \& data by applying credit Zip code system, direct the bank funded operations effectively that reduces bank credit risks).

With regard to table (4), second domain results indicated that agreements average percentage was $93.8 \%$, acceptances average was 4.43 with standard deviation reached 0.63 , and $\mathrm{T}$ value was 12.1 as its significance at (0.01) level.

*According to the mentioned above, we concluded refusal on nonexistence $(\mathrm{H} 0)$ and acceptance on alternative assumption (H 1).

\section{Conclusion}

The study concluded that the comprehensive data and information provided by the application of credit Zip code system to bank customers reduce bank credit risks and bad loan, and to get banking funded operations more effective.

\section{References}

[1]. Saleh, R (2000): Comprehensive Banks and Egyptian Banking Board Development (national \& international comprehensive banking ", without a publisher, Alexandria.

[2]. Ghaim, A (2002), Credit and Funding Donation Decisions through Overall Strategy", Egypt.

[3]. Arshid, A \&Gouda, M (2003)," Credit Management", Dar Wael for publishing, Amman, first edition.

[4]. Farida, B (2003) "Policies and techniques of Banking Operation", university publishing office second edition, Algeria

[5]. Hammad, T(2003) "International Changes and its Reflections on Banks Works", el dar el gamieya, Egypt.

[6]. El Refaay, G\&Yassin, S(2004) "Information Department Role in Reducing Credit Risks (Field Study)', El Zaitouna Jordanian University, Amman, Jordan.

[7]. Hammad, T (2005) "Companies Governance, conceptions, principles \& experiences" "Bank Governance Applications", el dar el gamieya, Alexandria.

[8]. Ahmed, B (2005) "Banks Techniques in Loan Donation", graduation memo to get license certificate, El Aghwatt University.

[9]. Samir El Khatib, "Measure \& Manage Banks Risks", Monshaet El Maaref, Egypt, 2005.

[10]. Ahmed, D (2005)"Accounting Analysis by using financial Breakdown Prediction to Decrease Bank Credit Risks", financial \& commercial studies magazine, faculty of commerce, BeniSwef university, second and third editions, master research published in 2005 .

[11]. Hashad, N (2006) "Your Guidance for internal\&external Credit Classifications", Journal for scientific studies and researches, economical \& legal sciences, Vol. (28) no. (3)

[12]. Saleh, M\& Farida, M (2007) "Credit Risks - analyzing, measuring, managing and controlling it", Beskarah university, Algeria.

[13]. Hussein, R (2007) "Electronic Banking as an Introduction to Modernize Algerian Banks", scientific texts group for the first national meeting about Algerian banking system and the economic changes, fact and aspiration.

[14]. El Kowary, M (2010) "Credit Agencies and its Effect on developing the financial sector", research paper to attain master degree in Islamic funding presented by Islamic studies faculty in Qatar foundation for science, education and society development, Doha, Qatar, published 2010.

[15]. Shahin, A (2010) "Practical Introduction for Bank Credit Risks Measurement in Palestine Commercial Banks", Islamic university, Ghaza, April 2010

[16]. Musaad, I (2010) "The Effect of Loan Bad Fund on Financial Performance for Sudanese Commercial Banks".

[17]. Muhammad,A (2012) "Credit Information Role in Banks Performance Promotion", research paper published in El Masrafy magazine, central bank release in 2012 .

[18]. Rezaif, K (2012), a research paper "Precaution and Risks Management in Algeria Banks and Financial Firms, El BolaidahUniversity, Algeria.Reports:

[19]. Arab Monetary Fund, Basic Features for Basel Agreement 2 and the Developing Countries, Abu Dhabi, 2004, pages.11-12.

[20]. El Rajhi Capital, "Basel Agreement" a Scientific Approach, economic researches, Saudi Arabia, October 2010, Page. 1.

[21]. Banking Studies Institute, awareness bulletin, highlights, Vol.5, no. 5, Kuwait. December 2012.

[22]. Economic Bulletin Bank, "the importance of banks competitive ability to confront the Current Challenges", Cairo, December 2000, page. 16.

[23]. Economic Bulletin, Deposits Insurance, Egypt, the thirty seventh year 1994, page. 67. 